\title{
Investigasi Sikap Sosial yang dimiliki oleh Siswa Kelas XI di SMAN 3 Kota Jambi pada Mata Pelajaran Fisika
}

\author{
Murniati $^{1}$, Erika $^{2}$ \\ ${ }^{1}$ MTsN 4 Kota Jambi, Jambi, Indonesia \\ ${ }^{2}$ Pendidikan Fisika, Universitas Jambi, Jambi, Indonesia
}

\begin{tabular}{l}
\hline \hline Article Info \\
\hline Article history: \\
Received Mar 10, 2020 \\
Revised Mei 3, 2020 \\
Accepted Jul 8, 2020 \\
\hline
\end{tabular}

\section{Keywords:}

Sekolah Menengah Atas

Sikap Sosial

Siswa

\begin{abstract}
ABSTRAK
Tujuan penelitian: Adapun tujuan dari penelitian ini untuk mengetahui deskripsi sikap sosial yang dimiliki oleh siswa kelas XI di SMAN 3 Kota Jambi. Untuk mengetahui kendala dalam pengembangan sikap sosial yang dimiliki oleh siswa kelas XI di SMAN 3 Kota Jambi.

Metodologi: Penelitian ini termasuk kedalam penelitian campuran (mix method). Data kualitatif didapatkan menggunakan lembar instrument wawancara. Sedangkan untuk data kuantitatif diperolah dengan menggunakan metode survey dan teknik pengumpulan data berupa angket.

Temuan utama: Hasil dari penelitian ini menunjukkan bahwa $46 . \%$ peserta didik memiliki sikap jujur yang baik, 63.3\% memiliki sikap disiplin yang sangat baik, 53.3\% telah memiliki sikap tanggung jawab yang sangat baik, $53.3 \%$ telah memiliki sikap santun yang baik, 50\% memiliki sikap peduli yang baik, dan $36.6 \%$ memiliki sikap percaya diri yang cukup baik.
\end{abstract}

Keterbaruan penelitian: Keterbaruan dari penelitian ini yaitu idikator yang digunakan untuk melihat sikap sosial peserta didik pada pembelajaran fisika.

This is an open access article under the $\mathrm{CCBY-NC}$ license

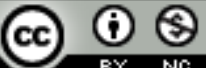

\section{Corresponding Author:}

Erika,

Fakultas Keguruan dan Ilmu Pendidikan, Universitas Jambi, Jambi, Indonesia

Email: erika.er@gmail.com

\section{PENDAHULUAN}

Manusia adalah makhluk individu dan sosial. Artinya yaitu bahwa manusia merupakan perpaduan antara aspek individu sebagai perwujudan dirinya sendiri, dan makhluk sosial dalam anggota kelompok atau masyarakat [1]. Sebagai mahkluk individu dan juga sosial, manusia akan menampilkan tingkah laku tertentu. Tingkah laku tersebut akan saling mempengaruhi dan akan menimbulkan sikap sosial tertentu. Sikap adalah sebuah penilaian subjektif seseorang terhadap objek [2]. Sikap tersebut tidak dapat diungkapkan dengan katakata, melainkan dengan memperhatikan perbuatan objek tersebut. Sikap dibagi kedalam 2 bagian, yaitu 1) sikap positif adalah sikap yang menyetujui, memperlihatkan, dan juga melaksanakan norma-norma yang berlaku disekeliling lingkungan individu itu berada dan 2) sikap negatif adalah sikap yang tidak menyetujui, memperlihatkan penolakan dan tidak melaksanakan norma yang berlaku dilingkungan individu itu berada[3]. Sedangkan sikap sosial adalah kesadaran masing-masing individu untuk menentukan perbuatan nyata yang berulang terhadap suatu objek. Sikap sosial juga terjadi pada dunia pendidikan. pendidikan sebagai usaha yang disadari serta didasari guna mewujudkan suasana belajar dan proses belajar agar peserta didik secara aktif mampu mengembangkan potensi yang ada pada dirinya [4].

Pendidikan adalah suatu proses pembelajaran kepada peserta didik agar memiliki pemahaman terhadap sesuatu[5]. Pendidikan diartikan sebagai usaha sadar dan terencana untuk mewujudkan suasana belajar dan proses pembelajaran agar peserta didik secara aktif mengembangkan potensi dirinya untuk 
memiliki kekuatan spiritual keagamaan, pengendalian diri, kepribadian, kecerdasan, akhlak mulia, serta keterampilan yang diperlukan dirinya, masyarakat bangsa dan Negara [6]. Pendidikan merupakan ujung tombak dalam pengembangan sumber daya manusia sehingga pendidikan harus berperan aktif dalam meningkatkan kualitas dan kuantitas pola pikir peserta didik [7]. Pendidikan di Indonesia telah terintegrasi dengan baik dan membutuhkan pengembangan lebih lanjut [8]. Pendidikan merupakan aktivitas untuk mencapai suatu tujuan yang telah ditetapkan [9]. Pendidikan adalah upaya untuk memberikan pengetahuan, wawasan, keterampilan,dan keahlian tertentu kepada manusia untuk mengembangkan bakat serta kepribadian [10]. Sebagai agen perubahan, pendidik diharapkan mampu menanamkan ciri-ciri, sifat dan watak serta jiwa mandiri, tanggung jawab dan cakap dalam kehidupan kepada peserta didik [11]. Tingkatan pendidikan perlu ditempuh karena dengan tingkatan, proses belajar dapat berjalan sesuai dengan kemampuan dan mampu menambah pengalaman, wawasan dan lain-lain [12].

Pendidikan terdiri dari beberapa jenjang, salah satunya yaitu jenjang SMA (Sekolah Menengah Atas). IPA merupakan salah satu mata pelajaran yang harus dipelajari di sekolah menengah pertama [13]. Ilmu Pengetahuan Alam (IPA) sudah mulai diperkenalkan kepada siswa sejak dini [14]. IPA menjadi bagian dari dasar perkembangan teknologi informasi, transportasi, dan produksi energy [15]. IPA merupakan ilmu yang lahir dan berkembang lewat langkah-langkah observasi, perumusan masalah, penyusunan hipotesis, pengujian hipotesis melalui eksperimen, penarikan kesimpulan serta perumusan teori dari konsep [16]. Pada hakikatnya IPA dibangun atas dasar produk ilmiah, proses ilmiah dan sikap siswa [17]. Sebagai suatu proses, Ilmu Pengetahuan Alam merupakan proses yang dipergunakan untuk mempelajari objek studi, menemukan dan mengembangkan produkproduk sains dan sebagai aplikasi, teori-teori [18].

Fisika merupakan cabang ilmu dari IPA. Ilmu Pengetahuan Alam Fisika adalah studi tentang fenomena alam dan interaksi di dalamnya melalui pengamatan, pengukuran, dan analisis [19]. Ilmu pengetahuna alam fisika yang merupakan salah satu cabang ilmu pengetahuan memiliki keunikan tersendiri karena didalamnya terdapat konsep-konsep abstrak dan membutuhkan idealisasi melalui pemodelan matematis [20]. Fisika merupakan salah satu bidang dari ilmu sains yang mempelajari tentang kejadian dan fenomena alam serta interaksi antara benda-benda di alam. Dalam mata pembelajaran fisika, selain melakukan penilaian kognitif dan psikomotor, guru juga melakukan penilaian sikap [21]. Fisika ilmu yang lahir dan berkembang lewat langkah-langkah observasi, perumusan masalah, penyusunan hipotesis, pengujian hipotesis melalui eksperimen, penarikan kesimpulan serta perumusan teori dari konsep [22].

Pendidikan adalah kegiatan yang penting bagi setiap manusia, karna dengan adanya pendidikan dapat merubah pengetahuan serta sikap atau tingkah laku menjadi lebih baik [23]. Seperti halnya kemampuan yang lain, bahwa sikap sosial juga dipengaruhi oleh beberapa faktor. Sikap timbul karena adanya pengaruh dari stimulus. Sikap akan terbentuk karena adanya pengaruh dan rangsangan dari luar [24]. sikap adalah hal yang paling utama yang dilihat dari peserta didik untuk menilai hal yang disukai dan yang tidak disukainya [25]. Tidak hanya dapat melihat hal yang disukai atau tidak disukai oleh peserta didik, sikap seorang peserta didik akan menentukan keberhasilan peserta didik dalam menyerap materi pada saat pembelajaran [26].

Setiap siswa memiliki kemampuan yang berbeda [27]. Keberhasilan proses pembelajaran merupakan tujuan yang ingin dicapai dalam melaksanakan pendidikan di sekolah [28]. Sikap sosial yang terjadi dipengaruhi oleh lingkungan sosial. Lingkungan sosial tersebut dapat berupa lingkungan sekolah, masyarakat, dan keluarga. Apabila lingkungan sosial memvasilitasi serta memberikan peluang untuk perkembangan anak secara baik dan positif, maka anak tersebut akan mancapai perkembangan sosial yang matang [29]. Dan begitu pula sebaliknya, saat lingkungan sosial tidak memvasilitasi dan tidak memberi peluang untuk perkembangan anak secara baik, maka perilaku anak tersebut akan cendrung negatif dan menyimpang. Untuk itu perlu diperhatikan perkembangan sikap sosial peserta didik untuk melihat kematangan peserta didik.

Keberhasilan yang dilakukan oleh guru dalam membentuk dan membina sikap sosial peserta didik akan membentuk individu-individu yang memiliki serta mengamalkan sikap sosial dalam kehidupan seharihari. Sikap sosial yang dimaksud menurut kurikulum 2013 yaitu :

1. Jujur yaitu perilaku yang didasarkan pada upaya menjadikan dirinya sebagai orang yang selalu dapat dipercaya dalam perkataan, tindakan, dan pekerjaan.

2. Disiplin yaitu tindakan yang menunjukkan perilaku tertib dan patuh.

3. Tanggung jawab yaitu sikap dan perilaku peserta didik untuk melaksanakan tugas dan kewajibannya.

4. Santun yaitu perilaku hormat pada orang lain dengan bahasa yang baik.

5. Peduli yaitu sikap dan tindakan yang selalu ingin memberi bantuan.

6. Percaya diri yaitu suatu keyakinan atas kemampuannya sendiri.

Sikap sosial sangat perlu ditanamkan disekolah karena peserta didik menghabiskan sebagian waktunya di sekolah. Dan untuk membentuk sikap sosial yang baik pada siswa tidak terlepas dari adanya peran guru atau pendidik. Agar pendidik mampu menunaikan tugasnya, maka pendidik harus paham dengan 
keadaan siswa secara individu dan kelompok, dan juga dalam pembentukan sikap serta kepribadiannya dalam penanaman sikap sosial. Untuk itu sikap sosial sangat penting ditanamkan di sekolah.

Penjabaran diatas menunjukkan bahwa sikap sosial sangat diperlukan. Berdasarkan hal tersebut, dirasa perlu untuk diadakannya penelitian untuk mendeskripsikan sikap sosial peserta didik kelas XI IPA di SMA Negeri 3 Kota Jambi. Dengan demikian diadakanlah penelitian dengan judul "Investigasi Sikap Sosial Yang Dimiliki Oleh Siswa Kelas XI Di SMAN 3 Kota Jambi Pada Mata Pelajaran Fisika".

\section{METODE PENELITIAN}

Jenis penelitian yang digunakan adalah jenis penelitian Mix method tipe parallel-konvergen. Mixed method data collection strategies are those that are explicitly designed to combine elements of one method[30]. Maksudnya yaitu strategi pengumpulan data campuran merupakan srategi yang menggabungkan antara 2 teknik dari suatu metode. Pada penelitian ini, peneliti menggabungkan antara penelitian kualitatif dan kuantitatif. Untuk penelitian kualitatif, teknik yang digunakan adalah wawancara dengan instrumen lembar wawancara. Sedangkan untuk penelitian kuantitatif data dikumpulkan menggunakan instrument angket. Menurut Darmawangsa (2018) angket merupakan alat ukur sikap. Instrument angket yang peneliti gunakan merupakan angket adopsi dari skripsi Anisabellah tahun 2007. angket adalah daftar pertanyaan yang digunakan sebagai perisert untuk memperoleh data secara langsung dari orang yang bersangkutan. Skala yang peneliti gunakan adalah skala likert[31]. skala psikometrik yang umum digunakan pada kuisioner, penilaian responden ditentukan dari tingkat persetujuan responden terhadap pertanyaan[32].

Berikut kisi-kisi angket pengukuran sikap sosial yang digunakan dalam penelitian ini :

Tabel 1. Kisi-kisi angket pengukuran sikap sosial

\begin{tabular}{ll}
\hline Dimensi sikap & Nomor butir \\
\hline Jujur & $15,16,18,19$ \\
Disiplin & $3,9,17,26,27,28,29$ \\
Tanggung jawab & $1,2,4,5,6,8,10,20,24,25$ \\
Santun & 30 \\
Peduli & $7,11,12,13,14$ \\
Percaya & $21,22,23$ \\
\hline
\end{tabular}

Alternatif yang digunakan oleh peneliti adalah alternatif selalu (S) dengan poin 5, sering (SR) dengan poin 4, kadang kadang (KK) dengan poin 3, jarang (J) dengan poin 2, dan tidak pernah (TP) dengan poin 1 . Seluruh pernyataan yang digunakan adalah pernyataan positif, sehingga semua prnyataan memiliki nilai skala yang sama. Berikut merupakan klasifikasi indikator sikap sosial siswa :

Tabel 2. Klasifikasi indikator sikap sosial

\begin{tabular}{ccccccc}
\hline & \multicolumn{3}{c}{ Rentang } & \multirow{2}{*}{ Klasifikasi } \\
\cline { 1 - 5 } Indikator 1 & indikator 2 & Indikator 3 & Indikator 4 & Indikator 5 & Indikator 6 & \\
\hline $5,0-8,0$ & $7,0-12,5$ & $10,0-18,0$ & $1,0-1,8$ & $5,0-9,0$ & $3,0-5,4$ & Tidak baik \\
$8,1-11,0$ & $12,6-18,1$ & $18,1-26,0$ & $1,9-2,6$ & $9,1-13,0$ & $5,5-7,8$ & Kurang baik \\
$11,1-14,0$ & $18,2-23,7$ & $26,1-34,0$ & $2,7-3,4$ & $13,0-17,0$ & $7,9-10,2$ & Cukup baik \\
$14,1-17,0$ & $23,8-29,3$ & $34,1-42,0$ & $3,5-4,2$ & $17,1-21,0$ & $10,3-12,6$ & Baik \\
$17,1-20,0$ & $29,4-35,0$ & $42,1-50,0$ & $4,3-5,0$ & $21,1-25,0$ & $12,7-15,0$ & Sangat baik \\
\hline
\end{tabular}

Penelitian ini dilakukan di SMA 3 Kota Jambi. Sampel dari penelitian ini di ambil secara acak (simple random sampling) dengan tidak memperhatikan jenis kelamin, prestasi, usia atau apapun. Adapun jumlah sampel dalam penelitian ini 60 responden yang terdiri dari 42 perempuan dan 18 laki-laki. Teknik analisis yang digunakan untuk data kuantitatif adalah analisis statistic deskriptif menggunakan aplikasi SPSS.

\section{HASIL DAN PEMBAHASAN}

Sikap adalah salah satu faktor yang mempengaruhi berlangsungnya proses pembelajaran yang berasal dari dalam diri peserta didik [33]. Setiap manusia tentunya memiliki karakter yang berbeda beda. karakter tersebut dapat kita lihat dari bagaimana seseorang tersebut berinteraksi makhluk hidup disekitarnya. Interaksi itu disebut dengan sikap sosial. Pada dunia pendidikan, terjadi interaksi sosial antara guru dan peserta didik serta antara sesama peserta didik. 


\subsection{Jujur}

Hasil analisis statistik yang diperoleh mengenai sikap peserta didik yang ditinjau dari indikator jujur dapat dilihat pada tabel dibawah ini:

Tabel 3. Sikap sosial jujur dari peserta didik kelas XI SMAN 3 Kota Jambi

\begin{tabular}{cccc}
\hline Rentang & Kategori & Frekuensi & Persen(\%) \\
\hline $5,0-8,0$ & Tidak baik & 0 & 0 \\
$8,1-11,0$ & Kurang baik & 1 & 1.7 \\
$11,1-14,0$ & Cukup baik & 14 & 23.3 \\
$14,1-17,0$ & Baik & 28 & 46.7 \\
$17,1-20,0$ & Sangat baik & 17 & 28.3 \\
\hline Jumlah & & 60 & 100 \\
\hline
\end{tabular}

Dari tabel dapat dilihat untuk rentang 5.0-8.0 merupakan rentang untuk kategori tidak baik. Tidak terdapat peserta didik yang memiliki sikap jujur yang tidak baik. Untuk rentang 8.1-11.0 merupakan rentang kurang baik. Pada rentang ini terdapat 1 dari 60 responden yang memiliki sikap jujur kurang baik, atau 1.7\%. rentang 11.1-14.0 merupakan rentang cukup baik, terdapat 14 dari 60 peseta didik atau $23.3 \%$. selanjutnya rentang 14.1-17.0 merupakan rentang baik, dengan jumlah peserta didik 17 dari 60 responden atau $46.7 \%$. dan rentang yang terakhir adalah 17.1-20.0 merupakan rentang dengan kategori sangat baik, yaitu terdapat 17 dari 60 peserta didik atau $28.3 \%$.

Sikap sosial merupakan sikap yang harus lebih ditanamkan oleh guru pada peserta didik, karena peserta didik menghabiskan banyak waktunya disekolah. Sikap jujur menggambarkan bagaimana siswa menerapkan nilai nilai kejujuran dalam kehidupan sosial. Pada tabel 3 mengungkapkan bahwa sikap siswa dominan pada kategori baik yaitu 46.7\% . hasil ini selanjutnya juga di dukung dengan hasil wawancara dibawah ini:

Question : apakah kamu mengerjakan sendiri soal ujian waktu ujian?

Answer : iya, saya mengerjakan sendiri. setiap kalu mau ujian, sehari sebelumnya saya selalu mempelahari ulang materi yang telah dipelajari.

\subsection{Disiplin}

Hasil analisis statistik yang diperoleh mengenai sikap peserta didik yang ditinjau dari indikator jujur dapat dilihat pada tabel dibawah ini:

Tabel 4. Sikap sosial disiplin dari peserta didik kelas XI SMAN 3 Kota Jambi

\begin{tabular}{cccc}
\hline Rentang & Kategori & Frekuensi & Persen $(\%)$ \\
\hline $7,0-12,5$ & Tidak baik & 0 & 0 \\
$12,6-18,1$ & Kurang baik & 0 & 0 \\
$18,2-23,7$ & Cukup baik & 1 & 1.7 \\
$23,8-29,3$ & Baik & 21 & 35.0 \\
$29,4-35,0$ & Sangat baik & 38 & 63.3 \\
\hline Jumlah & & 60 & 100 \\
\hline
\end{tabular}

Dari tabel dapat dilihat untuk rentang 7.0-12.5 merupakan rentang dengan kategori tidak baik, pada kategori ini tidak terdapat peserta didik yang memiliki sikap disiplin yang tidak baik. Selanjutnya untuk rentang 12.6-18.1 merupakan rentang dengan kategori kurang baik, pada kategori ini juga tidak terdapat peserta didik yangmemiliki sikap disiplin kurang baik. Untuk rentang berikutnya adalah 18.2-23.7 merupakan kategori cukup baik, pada kategori ini terdapat 1 dari 60 peserta didik yang memiliki sikap disiplin yang cukup baik atau 1.7\%. rentang berikutnya adalah 23.8-29.3 merupakan rentang dengan kategori baik, pada kategoti ini terdapat 21 dari 60 peserta didk atau 35\%. Dan rentang 29.4-35.0 merupakan kategori sangat baik, pada kategori ini terdapat 38 dari 60 peserta didik atau $63.3 \%$.

Faktor yang sangat mempengaruhi lancarnya proses belajar seorang siswa salah satunya adalah Disiplin terhadap semua peraturan. Di dalam pelaksanaan pengajaran, disiplin adalah suatu hal yang sangat penting. Tanpa adanya kesadaran untuk melaksanakan aturan yang sudah ditentukan sebelumnya pengajaran tidak mungkin mencapai target yang maksimal. Menurut Saoutra (2012) sikap yang sangat menunjang siswa untuk lebih maju dalam belajar adalah sikap, sikap disiplin harus diterapkan baik di lingkungan sekolah, di lingkungan rumah, maupun di perpustakaan. Pada tabel 4 mengungkapkan bahwa siswa dominan berkategori sangat baik yaitu 63.3\%. hal ini didukung dengan hasil wawancara berikut ini :

Question : Apakah kamu sering data telat kesekolah? 
Answer : tidak, karna saya selalu berangkat lebih awal untuk menghindari macet di jalan.

\subsection{Tanggung jawab}

Hasil analisis statistik yang diperoleh mengenai sikap peserta didik yang ditinjau dari indikator tanggung jawab dapat dilihat pada tabel dibawah ini:

Tabel 5. Sikap sosial tanggung jawab dari peserta didik kelas XI SMAN 3 Kota Jambi

\begin{tabular}{cccc}
\hline Rentang & Kategori & Frekuensi & Persen $(\%)$ \\
\hline $10,0-18,0$ & Tidak baik & 0 & 0 \\
$18,1-26,0$ & Kurang baik & 0 & 0 \\
$26,1-34,0$ & Cukup baik & 3 & 5.0 \\
$34,1-42,0$ & baik & 25 & 41.7 \\
$42,1-50,0$ & Sangat baik & 32 & 53.3 \\
\hline Jumlah & & 60 & 100 \\
\hline
\end{tabular}

Dari tabel dapat dilihat bahwa untuk rentang 10-18.0 merupakan rentang dengan kategori tidak baik, tidak terdapat peserta didik yang memiliki sikap tanggung jawab yang tidak baik. Untuk rentang 18.2-26.0 merupakan rentang dengan kategori kurang baik, pada rentang ini juga tidak terdapat peserta didik dengan kategori kurang baik ini. Selanjutnya untuk rentang 26.1-34.0 merupakan rentang dengan kategori cukup baik, pada rentang ini terdapat 3 dari 60 peserta didik yang memiliki sikap tanggung jawab yang cukup baik. Untuk rentang 34.1-42.0 merupakan rentang dengan kategori baik, terdapat 25 dari 60 peserta didik yang memiliki sikap tanggung jawab yang baik. Dan rentang 42.1-50 merupakan rentang dengan kategori sangat baik. Pada kategori ini terdapat 32 peserta didik atau $53.3 \%$.

Sikap tanggung jawab merupakan sikap yang menunjukkan bahwa seseorang merupakan manusia yang beradab. Seseorang yang bertanggung jawab akan memikirkan baik buruk dari suatu perbuatan yang akan ia lakukan. Pada tabel 5 mengungkapkan bahwa siswa telah memiliki rasa tanggung jawab yang sangat baik yaitu 53.3\%. hal ini juga didukung oleh hasil wawancara dibawah ini :

Question : Apakah saat meminjam barang teman mu, kamu akan langsung megembalikannya saat setelah dipakai ?

Answer : iya, saya selalu mengembalikan kepada teman saya.

\subsection{Santun}

Hasil analisis statistik yang diperoleh mengenai sikap peserta didik yang ditinjau dari indikator jujur dapat dilihat pada tabel dibawah ini:

Tabel 6. Sikap sosial santun dari peserta didik kelas XI SMAN 3 Kota Jambi

\begin{tabular}{cccc}
\hline Rentang & Kategori & Frekuensi & Persen(\%) \\
\hline $1,0-1,8$ & Tidak baik & 0 & 0 \\
$1,9-2,6$ & Kurang baik & 2 & 3,3 \\
$2,7-3,4$ & Cukup baik & 10 & 16,7 \\
$3,5-4,2$ & baik & 32 & 53,3 \\
$4,3-5,0$ & Sangat baik & 16 & 26,7 \\
\hline Jumlah & & 60 & 100 \\
\hline
\end{tabular}

Pada tabel telihat bahwa rentang 1-1.8 merupakan rentang dengan kategori tidak baik, pada ktaregori ini tidak terdapat peserta didik yang memiliki sikap sosial santun yang tidak baik. Rentang 1.9-2.6 merupakan rentang yang memiliki katerori kurang baik, terdapat 2 dari 60 peserta didik yang memiliki sikap santun yang termasuk kedalam kategori kurang baik, atau 3.3\% dari responden. Rentang selanjutnya yaitu 2.7-3.4 merupakan kategori cukup baik, terdapat 10 dari 60 responden yang memiliki sikap santun yang cukup baik, atau sekitar 16.7\%. kategori cukup pada rentang 3.5-4.2, terdapat 32 dari peserta didik yang memiliki sikap santun yang baik, atau sekitar53.3\%. rentang berikutnya yaitu 4.3-5.0 merupakan rentang sangat baik, pada rentang ini terdapat 16 dari 60 responden yang bersikap santun, dengan frekuensi 16 responden atau $26.7 \%$.

Santun merupakan sikap yang harus ada pada diri sesorang. Sejak kecil sesorang telah diajarkan sopan santun oleh orang tuanya. Memiliki siksp santun merupakan model awal seseorang bisa dikatakan memiliki sikap sosial yang baik. Tabel 6 mengungkapkan bahwa dominan peserta didik telah berkategori baik, yaitu sebanyak 53.3\%. hal ini didukung dengan hasil wawancara sebagai beriku :

Question : apakah kamu selalu menyalami gurumu saat bertemu?

Answer : iya, saya selalu menyalami guru saya. 


\subsection{Peduli}

Hasil analisis statistik yang diperoleh mengenai sikap peserta didik yang ditinjau dari indikator peduli dapat dilihat pada tabel dibawah ini:

Tabel 7. Sikap sosial peduli dari peserta didik kelas XI SMAN 3 Kota Jambi

\begin{tabular}{cccc}
\hline Rentang & Kategori & Frekuensi & Persen $(\%)$ \\
\hline $5,0-9,0$ & Tidak baik & 0 & 0 \\
$9,1-13,0$ & Kurang baik & 2 & 3,3 \\
$13,1-17,0$ & Cukup baik & 18 & 30,0 \\
$17,1-21,0$ & Baik & 30 & 50,0 \\
$21,1-25,0$ & Sangat baik & 10 & 16,7 \\
\hline Jumlah & & 60 & 100 \\
\hline
\end{tabular}

Dari tabel dapat dilihat bahwa untuk rentang 5-9 meupakan rentang tidak baik, pada kategori ini tidak terdapat peserta didik yang memiliki kategori yang tidak baik ini. Selanjutnya untuk rentang 9.1-13 merupakan kategori kurang baik, pada rentang ini terdapat 2 dari 60 responden yang memiliki sikap peduli yang kurang baik. Selanjutnya rentang 13.1-17 merupakan rentang untuk kategori cukup baik, terdapat 18 peserta didik atau 30\% yang memiliki sikap sosial yang cukup baik. Selanjutnya dengan rentagn 17.1-21 adalah rentang baik, terdapat 30 peserta didik yang memiliki sikap peduli yang baik atau $16.7 \%$. dan rentang berikutnya adalah 21.1025 merupakan kategori sangat baik. Terdapat 10 atau 16.7 peserta didkk yang termasuk kedalam rentang ini.

Peduli merupakan suatu sikap kepekaan seseorang terhadap hal atau lingkugan disekitarnya. Rasa peduli memiliki dampak tehadap hubungan sosial seseorang. Tabel 7 menunjukkan bahwa peserta didik dominan berkategori baik, yaitu sebanyak 50\%. Hal ini didukung oleh wawancara berikut ini :

Question : Saat ada teman mu membuang sampah sembarangan, apa yang kamu lakukan ?

Answer : menegurnya dan memberi tahu agar membuang ke tempat sampah.

\subsection{Percaya diri}

Hasil analisis statistik yang diperoleh mengenai sikap peserta didik yang ditinjau dari indikator percaya diri dapat dilihat pada tabel dibawah ini:

Tabel 8. Sikap sosial percaya diri dari peserta didik kelas XI SMAN 3 Kota Jambi

\begin{tabular}{cccc}
\hline rentang & kategori & frekuensi & Persen $(\%)$ \\
\hline $3,0-5,4$ & Tidak baik & 0 & 0 \\
$5,5-7,8$ & Kurang baik & 6 & 10 \\
$7,9-10,2$ & Cukup baik & 22 & 36.6 \\
$10,3-12,6$ & baik & 20 & 33.3 \\
$12,7-15,0$ & Sangat baik & 12 & 20 \\
\hline Jumlah & & 60 & 100 \\
\hline
\end{tabular}

Dari tabel dapat peroleh bahwa tidak ada peserta didik yang memiliki tingkat percaya diri yang tidak baik, yaitu dengan rentang 3-5.4. selanjutnya untuk kategori kurang baik, dengan rentang 5.5-7.8 terdapat 6 dari 60 peserta didik yang memiliki sikap percaya diri yang kurang baik, atau sekitar $10 \%$. Selanjutnya untuk rentang 7.9-102 merupakan rentang cukup baik terdapat 22 dari 60 peserta didik, rentang 10.3-12.6 merupakan rentang baik terdapat 20 dari 60 peserta didik, dan 12.7-15 merupakan rentang sangat baik terdapat 12 dari 60 peserta didik.

Indikator sikap percaya diri pada siswa ialah salah satu kunci kesuksesan dalam kehidupan sosial karena tanpa adanya rasa percaya diri siswa tidak akan bisa berhasil berinteraksi dengan temantemannya. Tabel 8 menunjukkan bahwa siswa yang berkategori cukup baik, baik, dan sangat baik memiliki jumlah yang sama yaitu $30 \%$. Hal ini didukung dengan hasil wawancara berikut :

Question: apakah kamu yakin dengan jawaban mu saat menjawab soal ujian?

Answer : seringkali saya tidak yakin dengan jawaban yang telah saya jawab, walaupun saya sudah mempelajarinya sebelu hari itu.

Dari jawaban yang diberikan saat wawancara terlihat bahwa masih banyak peserta didik yang kurang percaya dengan dirinya dan pengetahuan yang ia ketahui. 


\section{KESIMPULAN}

Dari hasil penelitian dapat diketahui bahwasannya sikap sosial tersebut beragam. Terdapat 6 indikator pada sikap sosial, yaitu jujur, disiplin, tanggung jawab, santun, peduli, dan percaya diri. Hasil penelitian menunjukkan terdapat $46.7 \%$ peserta didik telah memiliki sikap sosial jujur yang baik, $63 \%$ yang telah memiliki sikap sosial disiplin yang sangat baik, 53\% yang memiliki sikap sosial tanggung jawab yang sangat baik, 53.3\% yang memiliki sikap sosial santun yang baik, 50\% memiliki sikap sosial peduli yang baik. Selanjutnya untuk sikap sosial percaya diri, hasil penelitian menunjukkan bahwa $36.6 \%$ peserta didik termasuk kedalam kategori cukup baik.

Sikap sosial ini mempengaruhi cara berinteraksi peserta didik dengan teman sebaya dan gurunya. Dimana nantinya akan berdampak pula pada pengetahuan yang dimiliki oleh peserta didik. Saran untuk pihak sekolah adalah agar lebih memperhatikan lagi bahwasannya penerapan sikap sosial disekolah itu sangatlah penting karena sebagian besar peserta didik memghabiskan waktunya disekolah.

\section{UCAPAN TERIMA KASIH}

Saya mengucapkan ribuan terimakasih kepada semua pihak yang telah membantu saya dalam hal melakukan penelitian ini. Selajutnya saya juga terimakasih telah diberikan dukungan dalam menyelesaikan penelitian ini

\section{REFERENSI}

[1] Sumaatmadja, Narsid. "Manusia Dalam Konteks Sosial Budaya Dan Lingkungan Hidup".Bandung : CV. Alfabeta. 1998.

[2] Baron \& Byrne. "Psikologi Sosial". Jakarta: Erlangga. 2005.

[3] Ahmadi, Abu. "Ilmu Sosial Dasar". Jakarta: PT. Rineke Cipta. 1991.

[4] Undang undang nomor 20 tahun 2003

[5] Romdona.D.D and Adila.D. "Analisis Kemampuan Berpikir Kritis Siswa SMA Pada Materi Gerak Harmonik Sederhana”. Schrödinger:Journal of Physics Education (SJPE).vol.1. no.2. 2020

[6] Harizon, H., Haryanto, H., \& Anisah, A. "Pengaruh Penerapan Model Pembelajaran Kooperatif Tipe Make-A Match Terhadap Hasil Belajar Siswa pada Materi Larutan Elektrolit dan Nonelektrolit di SMA PGRI 2 Kota Jambi". Journal of The Indonesian Society of Integrated Chemistry, vol.8. no.2, 47-56. 2016.

[7] Utama, Z. P., Maison, M., and Syarkowi, A. “Analisis Kemampuan Bernalar Siswa SMA Kota Jambi”. Jurnal Penelitian Pembelajaran Fisika, vol.9. no.1,pp. 1-5. 2018.

[8] Maison, M., Darmaji, D., Kurniawan, D. A., Astalini, A., Dewi, U. P., and Kartina, L. :Analysis of science process skills in physics education students". Jurnal Penelitian dan Evaluasi Pendidikan, vol.23. no.2. 2019.

[9] Tanti, T., Rahim, U., and Samparadja, H. "Pengaruh Model Problem Based Learning Terhadap Kemampuan Pemecahan Masalah Matematis Siswa Kelas Vii Smp Negeri 14 Kendari”. Jurnal Penelitian Pendidikan Matematika, vol.8. no.2, 169-182. 2020.

[10] Haryanto, H. "Pengembangan Instrumen Penilaian Afektif Pada Materi Laju Reaksi Di Prodi Pendidikan Kimia Fkip Universitas Jambiz'. SEMIRATA 2015.

[11] Dewi, R., Budiarti, R. S., and Aina, M. "Pengembangan lembar kegiatan peserta didik (lkpd) bermuatan pendidikan karakter dengan model pembelajaran guided inquiry pada materi bakteri bagi siswa kelas $\mathrm{x}$ sekolah menengah atas". BIODIK, vol.3. no.1,pp. 17-26. 2017

[12] Juita. "Identifikasi Konsentrasi Belajar Siswa di Sekolah Menengah Atas". Schrödinger:Journal of Physics Education (SJPE).vol.1. no.1. 2020.

[13] Tanti, T., Kurniawan, D. A., Perdana, R., and Wiza, O. H. " Comparison Of Student Attitudes Toward Natural Sciences In Rural Middle Schools In Jambi Province”. Ta'dib, vol.23. no.1,pp. 63-74.2020.

[14] Haryanto, H., Bakar, A., and Ilahi, M. A. N. " Studi Perbandingan Hasil Belajar pada Materi Tata Nama Senyawa Kimia Antara Model Kooperatif Tipe Stad Dengan Jigsaw Kelas X SMA Negeri 3 Kuala Tungkal”. Journal of The Indonesian Society of Integrated Chemistry, vol..7.no.2, pp.54-62.2015.

[15] Tanti, T., Jamaluddin, J., and Syefrinando, B. " Pengaruh Pembelajaran Berbasis Masalah terhadap Beliefs Siswa tentang Fisika dan Pembelajaran Fisika”. Jurnal Ilmiah Pendidikan Fisika Al-Biruni, vol.6. no.1, pp. 23-36.2017.

[16] Haryanto, H., Harizon, H., and Ratih, N. K. "Pengembangan Instrumen Penilaian Keterampilan Proses dan Sikap Ilmiah pada Materi Termokimia Kelas XI MIA SMA Negeri 10 Kota Jambi”. Journal of The Indonesian Society of Integrated Chemistry, vol.8. no.1,pp. 50-62. 2016. 
[17] Susltiani.E,. Budiarti, R.S. Muswita.M. "Analisis Kemampuan Berpikir Kritis Siswa Lintas Minat Pada Pembelajaran Biologi Kelas X Iis Sma Negeri 11 Kota Jambi”. BIODIK: Jurnal ilmiah pendidikan biologi. Vol.2. no.1 2016

[18] Harlis, H., and Budiarti, R. S. "Pengembangan bahan ajar praktikum dan instrumen penilaian berbasis keterampilan proses sains pada mata kuliah mikologi program studi pendidikan biologi universitas jambi”. BIODIK, vol.3. no.2, pp. 102-112. 2017.

[19] Melisa.D. "Identifikasi Konsentrasi Siswa Di SMAN 10 Batang Hari”. Schrödinger:Journal of Physics Education (SJPE).vol.1. no.1.2020.

[20] Tanti, T., Maison, M., Mukminin, A., Syahria, S., Habibi, A., and Syamsurizal, S. "Exploring the relationship between preservice science teachers'beliefs and self-regulated strategies of studying physics: a structural equation model".Journal of Turkish Science Education, vol.15. no.4, pp. 79-92. 2018

[21] Rahayu, A., and Desma Romadona, D.D, "Deskripsi Implikasi Sosial dari Fisika, Sikap Terhadap Penyelidikan dalam Fisika dan Adopsi dari Sikap Ilmiah," Schrödinger:Journal of Physics Education (SJPE), vol. 1, no. 1, pp. 13-17, 2020.

[22] Haryanto, H., Harizon, H., and Ratih, N. K, "Pengembangan Instrumen Penilaian Keterampilan Proses dan Sikap Ilmiah pada Materi Termokimia Kelas XI MIA SMA Negeri 10 Kota Jambi,” Journal of The Indonesian Society of Integrated Chemistry, vol. 8, no. 1, pp. 50-62, 2016.

[23] Astalini, Kurniawan.D.A, and Sumaryanti. "Sikap siswa terhadap pelajaran fisika di SMAN kabupaten Batanghari”. Jurnal ilmu pendidikan fisika. Vol 3 No. 2.2019

[24] Ahmadi, Abu. Ilmu Sosial Dasar. Jakarta: PT. Rineke Cipta. 1991.

[25] Astalini, Kurniawan.D.A, Sumaryanti. "Sikap siswa terhadap pelajaran fisika di SMAN kabupaten Batanghari". Jurnal ilmu pendidikan fisika. Vol 3 No. 2.2019

[26] Astalini, Kurniawan.D.A, Melsayanti.R,and Destianti.A, sikap terhadap mata pelajaran IPA di SMP se-Kabupaten muaro jambi. Lentera pendidikan. Vol.21 No.2.2018

[27] Herlina, H., Lukman, A., \& Maison, M. "Proses Berpikir Kreatif Siswa Tipe Sekuensial Abstrak dan Acak Abstrak pada Pemecahan Masalah Biologi”. Edu-Sains: Jurnal Pendidikan Matematika dan Ilmu Pengetahuan Alam, vol.5.no.1. 2016

[28] Asfadi, B., Yelianti, U., \& Budiarti, R. S. "Pengaruh Model Pembelajaran Berbasis Masalah (Problem Based Learning) Terhadap Hasil Belajar Biologi Siswa Kelas X SMA N 3 Kota Jambi”. Skripsi Jurusan Pendidikan Biologi Fakultas Keguruan dan IlmuPendidikan Universitas Jambi. 2014

[29] Danim, Sudarwan. "Perkembangan Peserta Didik". Bandung: CV. Alfabeta. 2011

[30] Axinn,W.G,. \& Pearce,L.D. "Mixed Method Data Collection Strategie". United States of America : Cambridge University Pres. 2006

[31] Istijanto. "Riset Sumber Daya Manusia, Cara Praktis Mendeteksi Dimensi- Dimensi Kerja karyawan". PT. Gramedia Pustaka Utama. Jakarta.. 2005.

[32] Much, I., Subroto, I., Farisa, S., and Haviana, C. Sistem Informasi Angket Pengukuran Skala Kebutuhan Materi Pembelajaran Tambahan Sebagai Pendukung Pengambilan Keputusan Di Sekolah Menengah Atas Menggunakan Skala Likert. Vol.1. no.2, pp. 1-12.2016

[33] Maison, Astalini, Kurniawan. D.A, and Sholihah.L.R. "deskripsi sikap siswa SMA negeri pada mata pelajaran fisika". Edusins. Vol.10 No.1.2018 